УДК 338.22:33.02

\title{
МОДЕЛЮВАННЯ ПРОЦЕСУ ФОРМУВАННЯ МЕХАНІЗМУ РЕГУЛЯТОРНОЇ ПОЛІТИКИ ДЕРЖАВИ
}

\author{
Колупаєва I. В., к.е.н., доцент (ХTЕІ КНТЕУ)
}

У статті вперше запропоновано використання прочесного підходу до формування механізму регуляторної політики держави шляхом моделювання. Визначено, шэо під формуванням механізму регуляторної політики держави мається на увазі складний прочес розроблення конщептуально-прикладних основ здійснення регуляторної політики. Тому вирішено процес формування механізму державної регуляторної політики представити за допомогою моделюванням. $B$ якості інструмента структурно-функиіонального моделювання використано AllFusion Process Modeler, який дозволив точно та деталізовано прописати всі процеси, інструменти та необхідні ресурси. Зроблено висновок, що впровадження запропонованої моделі формування механізму регуляторної політики держави дозволить сприймати регуляторну політику як важливу складову системи національної економіки країни та нівелювати цілий ряд негативних факторів у процесі їі здійснення.

Ключові слова: регуляторна політика, механізм регуляторної політики, моделювання, процесний підхід, модель, стратегія регуляторної політики держави.

\section{МОДЕЛИРОВАНИЕ ПРОЦЕССА ФОРМИРОВАНИЯ МЕХАНИЗМА РЕГУЛЯТОРНОЙ ПОЛИТИКИ ГОСУДАРСТВА}

\author{
Колупаева И. В., к.э.н., доцент (ХТЭИ КНТЭУ)
}

В статье впервые предложено использование процессного подхода к формированию механизма регуляторной политики государства путем моделирования. Определено, что под формированием механизма регуляторной политики государства подразумевается сложный процесс разработки конщептуально-прикладных основ осуществления регуляторной политики. Поэтому решено процесс формирования механизма государственной регуляторной политики представить с помощью моделирования. В качестве инструмента структурно-функционального моделирования использован AllFusion Process Modeler, который позволил точно и детализировано прописать все процессы, инструменты $u$ необходимые ресурсы. Сделан вывод, что внедрение предложенной модели формирования механизма регуляторной политики государства позволит воспринимать регуляторную политику как важную составляющую системы начиональной экономики странь $u$ нивелировать цельй ряд негативных факторов в процессе ее осущуествления.

Ключевые слова: регуляторная политика, механизм регуляторной политики, моделирование, процессный подход, модель, стратегия регуляторной политики государства. 


\section{MODELING OF FORMATION MECHANISM REGULATORY POLICY}

\section{Kolupaeva I.V., PhD in Economics, associate professor (Kharkov Trade and Economic Institute of KNUTE)}

This article first proposed the use of a process approach to the formation mechanism of regulatory policy through modeling. It was determined that during the formation mechanism of regulatory policy refers to a complex process of developing conceptual and applied through the implementation of regulatory policy. So decided the formation mechanism of regulatory policy to present through simulation. As an instrument of structural and functional simulation used AllFusion Process Modeler, which allowed the accurate and detailed register all the processes, tools and resources required. Concluded that implementation of the proposed model of the formation mechanism of regulatory policy will take regulatory policy as an important component of the national economy and reverse a number of negative factors in the process of its implementation.

Keywords: regulatory policy, mechanism of regulatory policy, modeling, process approach, a model strategy for regulatory policy.

Постановка проблеми. Становлення і розвиток національної економіки в Україні обумовлюється багатофакторним впливом формування конкурентного середовища в умовах поглиблення ринкових відносин. Просування і реалізація ідей сталого розвитку в умовах системної кризи i військового конфлікту вимагають від держави послідовності, наполегливості і професіоналізму. Посилення позитивних тенденцій i реалізація заходів щодо стабілізації соціально-економічних процесів знаходяться в прямій залежності від формування цілеспрямованої, послідовної та передбачуваної державної регуляторної політики та відповідних дій управлінських органів та влади. Враховуючи це, важливим $\epsilon$ формування механізму регуляторної політики, який дозволить державним органам здійснювати регулюючу діяльність в питаннях усунення корпоративних конфліктів, зменшення соціальної напруженості, сприяння ефективності діяльності вітчизняних підприємств, забезпечення економічних інтересів всіх учасників ринкових відносин, розвитку добросовісної конкуренції на товарних ринках важливим.

Аналіз останніх досліджень i публікацій. Серед вітчизняних та закордонних науковців, що зробили серйозний внесок у вирішення питань розробки та реалізації регуляторної політики держави, варто виділити І. Горобінську [1], О. Кілієвича [2], В. Малигу [6], Т. Мельник [7], О. Мордвінова [8], Р. Нолла [14], М. Погрібняк [9], Р. Радейко [13], Л. Сюроу [15] та ін. Разом 3 тим, спостерігається відсутність адаптивних регулюючих заходів держави щодо розвитку економіки, тому питання застосування методів моделювання 3 метою розробки рекомендацій щодо формування механізму регуляторної політики держави в сучасних умовах вимагають подальшого розроблення.

Формулювання мети статті. Метою статті $\epsilon$ моделювання процесу формування механізму регуляторної політики держави.

Виклад основного матеріалу дослідження. Розуміючи під механізмом регуляторної політики держави достатньо складне поняття, що включає такі елементи: цілі регулювання, форми регулювання, методи регулювання, інструменти регулювання, засоби впливу, важелі впливу, функції регулювання, принципи регулювання, суб'єкт та об'єкт регулювання, потреби та інтереси суспільства [4, с. 171], формування даного механізму представимо як складний процес розроблення концептуально-прикладних основ здійснення регуляторної політики, що пояснюється не лише недосконалістю теоретичного опрацювання, але й внаслідок багатогранності цього процесу та наявності значної кількості факторів впливу. 
Враховуючи те, що державне регулювання має складну багаторівневу структуру, а процес формування механізму регуляторної політики держави необхідно представити системно та комплексно, необхідним $є$ використанням структурно-функціонального моделювання.

Визначення та побудова структури процесу формування механізму регуляторної політики дозволить виявити та усвідомити цілі, склад і зміст процесу формування, організації планування та контролю за здійсненням регуляторної політики.

Зазначимо, що структура процесу формування механізму регуляторної політики, яка представляє собою ієрархічну декомпозицію процесу формування на складові частини, відповідає наступним правилам [5]: 1) кожен рівень ієрархії декомпозиції має закінчений вигляд та охоплює всю сукупність елементів процесу, що представлений на даному рівні деталізації; 2) характеристики елементів процесу на кожному рівні ієрархії структури $\epsilon$ порівнянними; 3) нижній рівень декомпозиції містить елементи, на основі яких можуть бути чітко та зрозуміло визначені всі дані, необхідні i достатні для здійснення регуляторної політики.
Використання

структурно-

функціонального підходу утворює основу інформаційної мови процесу формування механізму регуляторної політики, на якому спілкуються всі взаємодіючі учасники. Це пояснює необхідність використання даного підходу до побудови моделі.

Отже, процес моделювання було реалізовано 3 використанням одного 3 найбільш дієвих інструментів - AllFusion Process Modeler (BPwin). За допомогою методології IDEF0, особливістю якої $\epsilon$ перетворення вхідної інформації в вихідну, де інструменти управління обмежують або приписують певні умови виконання перетворень, а механізми відображають ресурси, що виконують ці перетворення, представлено модель формування механізму регуляторної політики держави на рис. 1.

Зазначимо, що застосування саме методології IDEF0 для побудови моделі передбачає наявність чітко сформульованої мети, єдиного суб'єкта моделювання і однієї точки зору. Запропонована модель представлена у вигляді діаграми, яка знаходиться всередині бланка, що має декілька інформаційних полей (табл. 1).

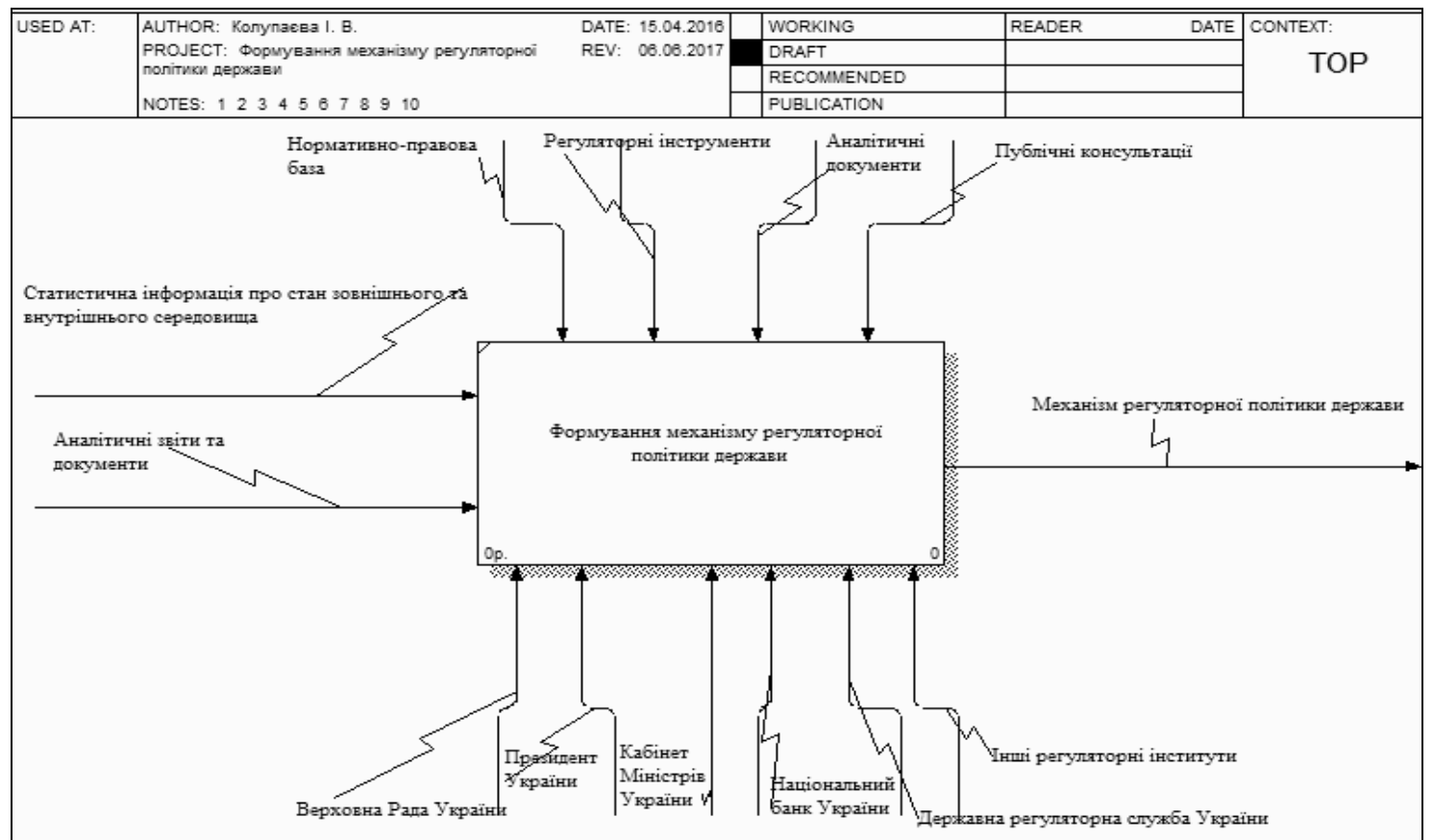

Рис. 1. Модель формування механізму регуляторної політики держави, яка розроблена у середовищі BPWin 
Табличя 1

Інформачійні поля прочесної моделі формування механізму регуляторної політики держави

\begin{tabular}{|l|l|}
\hline \multicolumn{1}{|c|}{$\begin{array}{c}\text { Інформаційні поля } \\
\text { моделі }\end{array}$} & \multicolumn{1}{|c|}{ Назва інформаційного поля } \\
\hline Model Name & Формування механізму регуляторної політики держави \\
\hline Definition & $\begin{array}{l}\text { Процесна модель, що описує етапи формування механізму } \\
\text { регуляторної політики держави } \\
\text { (AS-IS) }\end{array}$ \\
\hline Time Frame & Draft \\
\hline Status & Опитування експертів предметної області та аналіз документації \\
\hline Source & $\begin{array}{l}\text { Моделювати поточні (AS-IS) бізнес процеси розробки та } \\
\text { реалізації державної регуляторної політики }\end{array}$ \\
\hline Purpose & Колупаєва I. В. \\
\hline Author Name & 15.04 .2016 \\
\hline Creation Date & 06.06 .2017 \\
\hline System last Revision Date
\end{tabular}

3 інформаційної точки зору формування механізму регуляторної політики представлено у вигляді дослідження відомих заданих вхідних сигналів на змінні вихідні сигнали. В якості інструментів управління виступають, в першу чергу, регуляторні інструменти, що представляють собою сукупність практик, які використовуються в процесі розробки нового регулювання i поліпшення існуючого, процедури, стандарти, стратегії, що діють в країні. Для інформування громадськості про обраний курс дій важливими є програмні документи (Аналітичний документ міністерства, Зелена книга, Біла книга, Аналіз регуляторного впливу тощо). Також важливим $\epsilon$ використання такого інструменту, як публічні консультації, які, в свою чергу, використовуються в рамках інституту оцінки регулюючого впливу і дозволяють врахувати позиції всіх зацікавлених сторін.

Важливо зазначити, що процес формування механізму регуляторної політики існує у певному нормативноправовому полі діяльності. Тому правова та законодавча підтримка здійснення регуляторної політики регламентована законами, законодавчими, нормативноправовими та підзаконними актами, а також внутрішніми положеннями та певними регламентами, серед яких найбільш актуальними $є$ Закон України «Про засади державної регуляторної політики у сфері господарської діяльності» (№ 1160-15 від 26.11.2016) [10]; Постанова КМУ «Про затвердження методик проведення аналізу впливу та відстеження результативності регуляторного акта» (№ 308 від 11.03.2004 р.) [11]; Постанова КМУ і Нацбанку України «Про затвердження методик проведення аналізу впливу та відстеження результативності регуляторного акта Національного банку України» (від № 471 від 14.04.2004 p.) [12].

В якості механізму, а саме виконавців, виступає Президент країни та органи державної влади, яка відповідно до положень Конституції України поділяється на законодавчу (Верховна Рада України), виконавчу (Кабінет Міністрів України, Національний банк України, Національна рада України 3 питань телебачення i радіомовлення, інші державні органи, центральний орган виконавчої влади, місцевий орган виконавчої влади, орган місцевого самоврядування) та судову (Верховний суд України).

Важливо відзначити також регуляторні інститути, які $\epsilon$ основою для здійснення цілей регуляторної політики, а саме: Державна регуляторна служба України, Державна інспекція України з питань захисту прав споживачів, Державна служба статистики України, Державна фіскальна 
служба України, Національна комісія 3 цінних паперів та фондового ринку, Фонд державного майна України, Державна служба експортного контролю України, Антимонопольний комітет України тощо.

Отже, вхідна інформація представляє собою наявні можливості держави та ii середовища, що відзеркалюються у вигляді відповідних інформаційних потоків: статистична інформація про стан зовнішнього та внутрішнього середовища, аналітичні звіти.

Декомпозиція моделі формування механізму регуляторної політики дозволила виділити функціональні складові, відповідно до яких процес формування складається 3 наступних етапів: 1) визначення мети, завдань, загального бачення й строків формування механізму регуляторної політики держави; 2) проектування механізму регуляторної політики держави; 3) впровадження механізму регуляторної політики держави; 4) моніторинг механізму регуляторної політики держави та оцінка його якості; 5) розробка та реалізація профілактичних заходів щодо коригування механізму регуляторної політики держави.

Визначення мети, завдань, загального бачення й строків формування механізму регуляторної політики держави $є$ базовим початковим етапом в зазначеній моделі. При цьому акцентуємо увагу, що під метою розуміється, по-перше, бажаний результат діяльності, досягнутий в межах деякого інтервалу часу; по-друге, доказовий результат і задані умови реалізації спільного завдання.

Важливим процесом другого рівня на даному етапі $\epsilon$ обгрунтування необхідності регулювання, що можливо визначити завдяки аналізу неспроможності ринків держави. Розуміючи під неспроможністю ринку ситуацію, коли нерегульований ринок не може спрацювати ефективно (тобто коли розміщення ресурсів, обсяги виробництва благ i/aбо ціни не відповідають умовам ефективності ринку) [3, с. 31], визначимо, що неспроможність ринку функціонувати ефективно з огляду на економічні, соціальні, політичні та моральні чинники $є$ вагомою підставою для державного втручання.

Результуюча інформація першого етапу використовується для прогнозування динаміки розвитку національної економіки, зумовлює принципіальні особливості стратегії регуляторної політики держави, яку необхідно розробити. Даний етап дозволяє усвідомити наявні проблеми та першочергову необхідність та важливість формування механізму регуляторної політики держави.

Необхідно зазначити, що підготовчому етапу важливо приділяти підвищену увагу, а саме коректному та якісному плануванню аналізу функціонування впровадженого механізму. Це дозволить своєчасно отримати інформацію, необхідну для прийняття рішень 3 метою уникнення дублювання, а також для оцінки ефективності інвестицій. Окрім цього, в рамках підготовчого етапу слід робити акцент на аналізі проблеми, на яку направлено регулювання, оскільки саме від визначення ступеня ii важливості залежить той інструментарій, який буде згодом використаний для оцінки.

Етап безпосереднього проектування механізму регуляторної політики держави складається 3: виявлення факторів впливу на формування механізму регуляторної політики держави; розробки та взаємоузгодженності стратегічних цілей використання механізму регуляторної політики держави; визначення та обгрунтування сукупності інструментів (принципів, методів, функцій, важелів) державної регуляторної політики; формування ресурсного, організаційного, інформаційного та аналітичного забезпечення механізму; розробки стратегії регуляторної політики, іiі обгрунтування за універсальними

(результативність, справедливість, політична здійсненність, адміністративна здійсненність); вибору оптимальної стратегії регуляторної політики держави.

Перед тим як перейти безпосередньо до процесу проектування механізму 
регуляторної політики держави, необхідно визначити фактори впливу на формування механізму регуляторної політики держави та ретельно їх проаналізувати. Так, у монографії [4] запропоновано модель визначення впливу чинників на регуляторну політику 3 використанням апарату когнітивного моделювання, важливим етапом якої $є$ побудова матриці розміщення груп чинників за рівнем міжгрупового та внутрішньогрупового впливу. В основу реалізації даної моделі покладено частково використання методу оцінки зовнішнього середовища Вільсона (матричний аналіз складання профілю середовища) та експертне оцінювання відносної значущості окремих факторів середовища.

Зазначимо, що важливим завданням в контексті проектування механізму регуляторної політики держави $є$ визначення та обгрунтування сукупності інструментів (принципів, методів, функцій, важелів) державної регуляторної політики та формування ресурсного, організаційного, інформаційного та аналітичного забезпечення механізму. Так, в якості інструментарію у монографії [4] було зроблено наголос на принципах, методах, функціях, важелях. Принципи виокремлено як загальні та специфічні; функції - цільова, стимулююча, регламентуючу, коригуюча, соціальна, безпосереднє управління ринковим сектором економіки, контролююча, забезпечуюча; методи - за формою та засобом впливу; важелі - за характером та типом впливу.

Акцентуємо увагу, що при проектуванні та побудові механізму зосереджено увагу на формуванні ресурсного (синтезований капітал), організаційного (інституційнокадрове забезпечення, інституційноорганізаційне забезпечення регіонального, державного,

транскордонного, євроінтеграційного та світового рівнів), інформаційного (статистичні показники, рейтингові оцінки бізнес-середовища, звітність тощо) та аналітичного (методи аналізу) забезпечення здійснення регуляторної політики.
Необхідно зазначити, що ефективне впровадження механізму регуляторної політики держави припускає використання інструментарію стратегічного планування, тобто розробку та обгрунтування стратегії регуляторної політики, що $\epsilon$ важливим базисом в контексті формування та реалізації державної регуляторної політики.

3 точки зору автора, використання моделювання для оптимізації процесу розроблення та впровадження стратегії регуляторної політики дозволить усунути зайві зв'язки, інформаційні і матеріальні потоки, та відповідно мінімізувати витрати часу та засобів і забезпечити максимальну відповідність стратегії розвитку національної економіки. Тому насправді важливим питанням в контексті формування механізму регуляторної політики та відповідно реалізації стратегії $\epsilon$ доведення інформації про його впровадження до відома громадян країни та організацій, підприємств і установ. Зазначимо, що оприлюднення інформації про впровадження стратегії регуляторної політики держави має здійснюватися, в першу чергу, на офіційному сайті Державної регуляторної служби України.

Моніторинг механізму регуляторної політики держави та оцінка його якості включає в себе: аналіз ефективності регуляторної політики (аналіз ефективності діяльності органів системи регуляторної політики, аналіз результативності регуляторних актів, аналіз впливу регуляторної політики на національну економіку в цілому, аналіз дієвості важелів регуляторної політики); контроль досягнення запланованих цілей; створення системи контролю результативності впровадження механізму регуляторної політики держави; визначення результативності впровадження механізму регуляторної політики держави.

Встановлення прямого причиннонаслідкового зв'язку між змінами в регуляторній політиці i економічними результатами, який виражався б в кількісних показниках, $є$ складним, а іноді нездійсненним завданням. Тому надважливим підпроцесом $\epsilon$ комплексний 
аналіз ефективності регуляторної політики, який включає не тільки аналіз ефективності діяльності органів системи регуляторної політики та визначення результативності регуляторних актів, але й оцінку впливу регуляторної політики на національну економіку в цілому та аналіз дієвості важелів регуляторної політики. Це дозволить охарактеризувати ефективність політичного втручання $з$ метою розуміння, в першу чергу, регуляторного циклу. Окрім цього, важливо забезпечити відкритість проведення аналізу для громадян і зацікавлених сторін, а також необхідність проведення періодичних перевірок ефективності.

Для проведення якісного моніторингу результативності дії регуляторних актів та ефективності їх впливу на ділову активність і розвиток підприємництва, важливим кроком $\epsilon$ визначення параметрів оцінки (мета, тип оцінки, подальше використання результатів тощо) та врахування обмежень кожного 3 інструментів аналізу. Контроль досягнення цілей передбачає відстеження результатів впливу механізму.

Розробка та реалізація профілактичних заходів щодо коригування механізму регуляторної політики держави передбачає: проведення тренінгів, навчальних семінарів, професійних консультацій для працівників органів державної влади та органів місцевого самоврядування всіх рівнів, підприємців і їх структур стосовно реалізації державної регуляторної політики в сфері господарської діяльності; надання методичної допомоги районим державним адміністраціям, міським радам міст обласного значення щодо забезпечення впровадження механізму регуляторної політики; забезпечення вільного доступу громадським організаціям, підприємцям до інформації органів державної влади і місцевого самоврядування 3 питань впровадження регуляторної політики і поліпшення бізнес-середовища в країні.

Вихідною інформацією представленої процесної моделі є механізм регуляторної політики, використання якого дозволить: досягти максимально можливого збалансованого і стабільного економічного росту шляхом всебічного розвитку соціально-економічної системи; сформувати гідні умови життя і праці громадян країни в контексті реалізації соціальних цілей суспільства; забезпечити необхідний рівень інтеграційних зв'язків вітчизняної економіки зі світовою для збереження соціальноекономічної безпеки держави.

Таким чином, запропонована процесна модель представлена у вигляді елементарних етапів формування механізму регуляторної політики держави та його впровадження. Це дозволяє відстежувати i контролювати процес його розробки та реалізації на кожному конкретному етапі 3 метою оптимізації відповідних процесів та підпроцесів. Отже, організаційноуправлінське забезпечення процесу формування механізму регуляторної політики держави, яке включає інформацію про вхід та вихід моделі в рамках кожного процесу першого та другого рівня та відображає інструменти управління та механізми (виконавців), представлено в табл. 2.

Зазначимо, що вдосконалення i організаційної, і управлінської діяльності стосовно формування механізму регуляторної політики держави не потребує значних фінансових витрат. Важливішим стає правильне бачення і розуміння ситуації, бажання конструктивно та 3 мінімальними витратами вирішувати проблеми та демонструвати відповідальність та згуртованість.

Висновки. Запропонована процесна модель формування механізму регуляторної політики держави декомпозується на такі елементи: визначення мети, завдань, загального бачення й строків формування механізму регуляторної політики держави; проектування механізму регуляторної політики держави; впровадження механізму регуляторної політики держави; моніторинг механізму регуляторної політики держави та оцінка його якості; розробка та реалізація профілактичних заходів щодо коригування механізму регуляторної політики держави. 


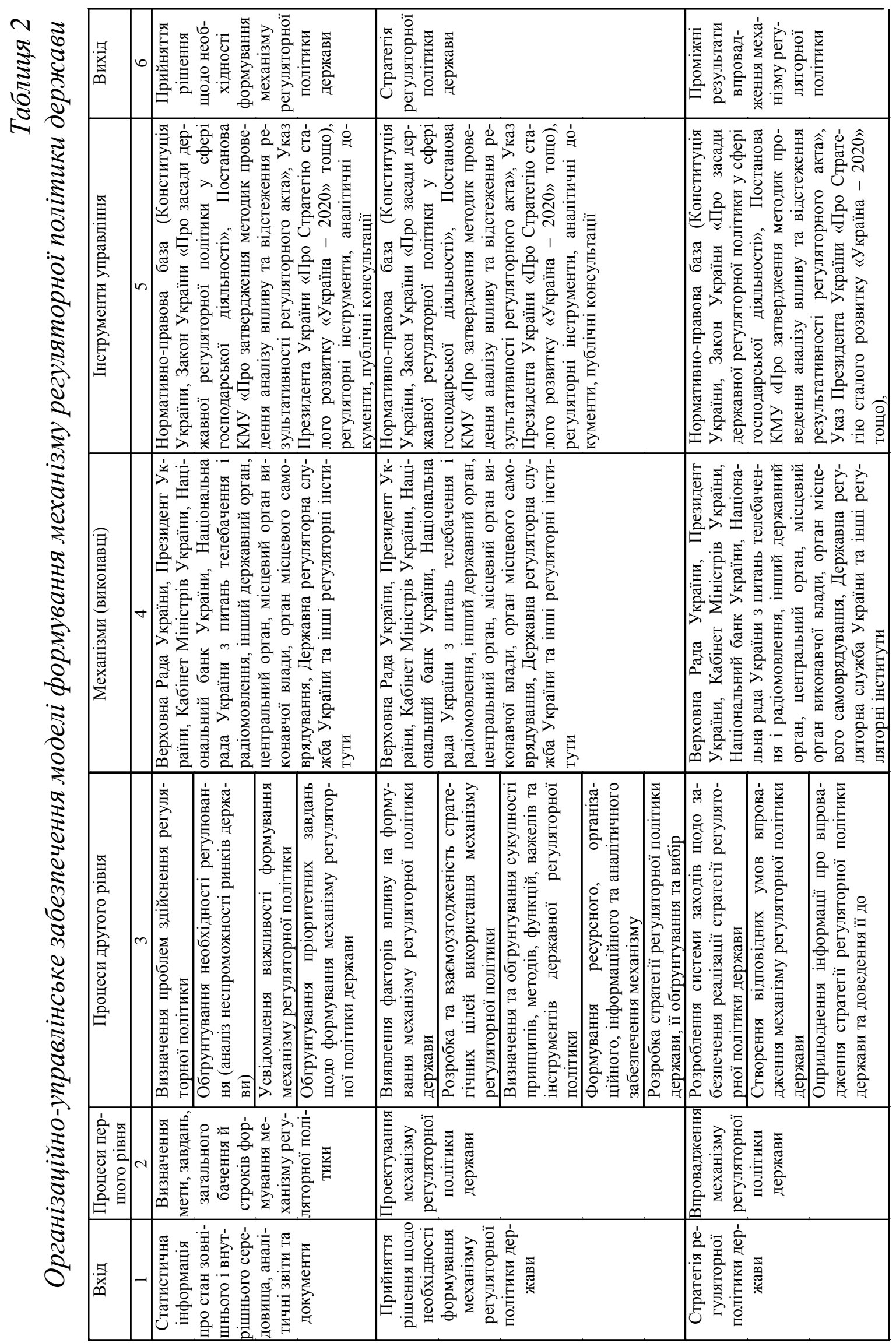

Вісник економіки транспорту і промисловості № 58,2017 


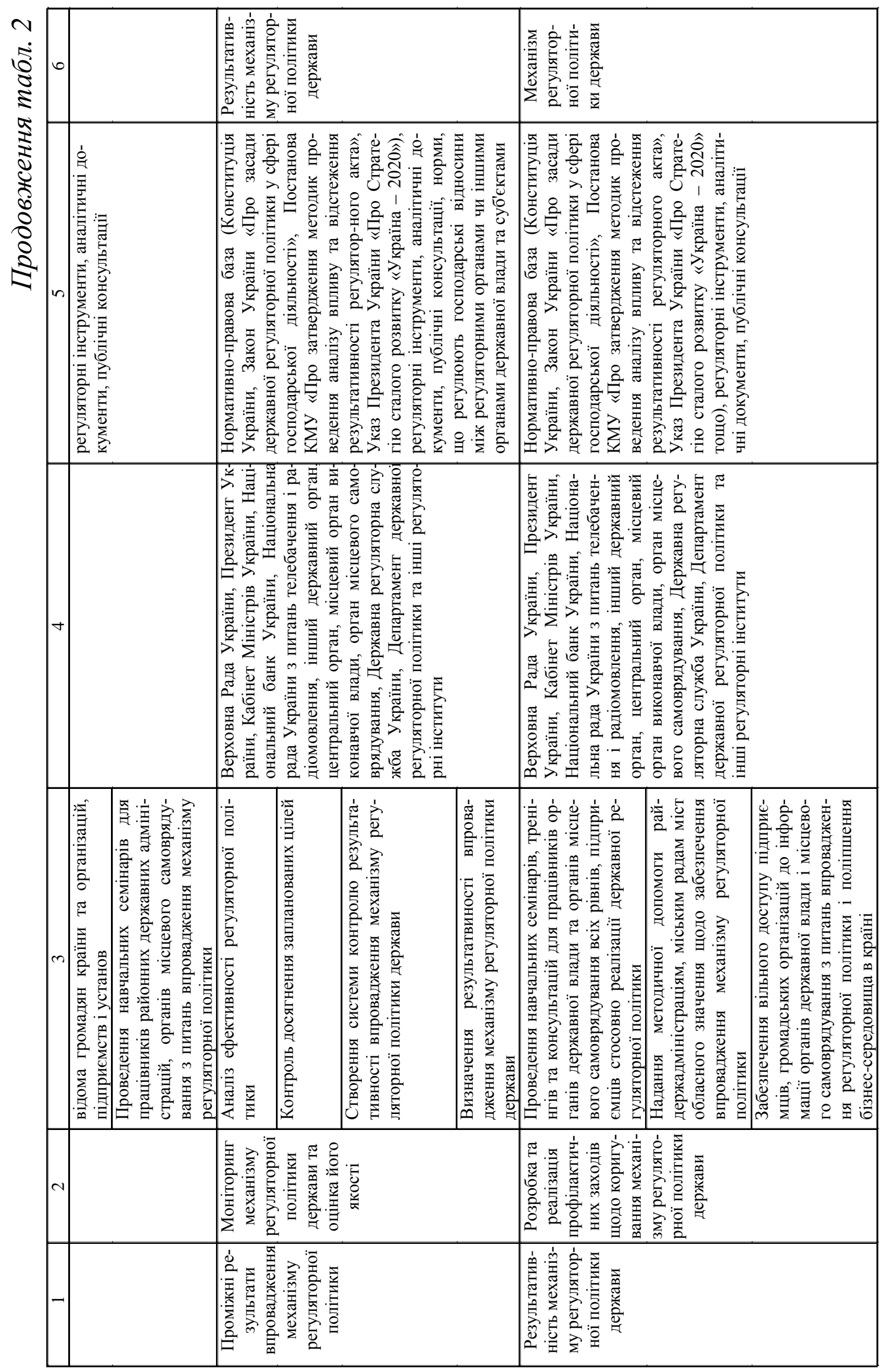

Вісник економіки транспорту і промисловості № 58, 2017 
Відповідно до процесної моделі, представлення механізму регуляторної політики у наочному вигляді базується на логіці, що будь-який механізм має відображувати взаємодію суб'єктів та об'єктів управління, враховувати вплив зовнішнього та внутрішнього середовища, а його дія визначається інструментарієм, тобто принципами, функціями, важелями, методами i наявністю забезпечення ресурсного, організаційного, інформаційного.

Таким чином, формування механізму регуляторної політики держави на основі концепції регуляторної політики та 3 використанням структурно-функціонального моделювання дозволить, 3 одного боку, забезпечувати загальну результативність державного регулювання, що має вплинути на покращення показників господарської діяльності, а 3 іншого - поширювати сучасну регуляторну політику, яка за змістом відповідає актуальним вимогам регуляторної політики високорозвинених країн. Слід підкреслити, що функціонування зазначеного механізму сприяє наявності синергетичного ефекту необхідної умови створення середовища, притаманного конкурентоспроможній державі.

\section{ПЕРЕЛІК ВИКОРИСТАНИХ ДЖЕРЕЛ}

1. Горобінська I. В. Механізм реалізації державної регуляторної політики в сфері транспортної діяльності / І. В. Горобінська // Вісник Національного транспортного університету. - 2011. - № 24 (1). - С. 232-236.

2. Енциклопедія

державного управління : у 8 т. / Нац. акад. держ. упр. При Президентові України ; наук. - ред. колегія : Ю. В. Ковбасюк та ін. - К. : НАДУ, 2011. Т. 4 : Галузеве управління / наук. - ред. колегія : М. М. Іжа, В. Г. Бодров та ін. $-2011 .-648$ с.
3. Кілієвич O. I. Економічний аналіз державної політики: навч. Посібник / О. І. Кілієвич. - К.: НАДУ, 2011. - 78 с.

4. Колупаєва I. В. Регуляторна політика держави: теорія та методологія: монографія / I. В. Колупаєва. - Харків: Видавництво ТОВ «Смугаста типографія», 2016. $-335 \mathrm{c}$.

5. Маклаков C. B. ERwin и BPwin. CASE-средства разработки информационных систем / С. В. Маклаков. - М. : ДИАЛОГ-МИФИ, 2000 - 256 с.

6. Малига В. А. Вплив перегляду регуляторних актів на реалізацію державної регуляторної політики / В. А. Малига // Науковий вісник Ужгородського національного університету. Серія ПРАВО. - 2014. - Випуск 29. Том 1. - С. 190-193.

7. Мельник Т. М. Розвиток національної регуляторної політики в процесі становлення глобальної торговельної системи : автореф.дис ... д-ра екон. наук : 08.00.02 / Т. М. Мельник; Держ. вищ. навч. закл. «Київ. нац. екон. ун-т ім. В.Гетьмана». - К., 2009. - 35 с.

8. Мордвінов О.Г. Досвід формування механізму регуляторної політики в США та можливості застосування його в Україні / О. Г. Мордвінов, М. А.Погрібняк [Електронний pecypc]. - Режим доступу: http: //www.nbuv.gov.ua/PORTAL/Soc_Gum/Ptd u/2011_2/files/PD211_28.pdf

9. Погрібняк М. А. Механізм державної регуляторної політики у сфері господарської діяльності: автореф. дис... канд. наук 3 держ. упр.: 25.00.02 / Погрібняк М. А.; Класич. приват. ун-т. Запоріжжя, 2008. - 20 с.

$$
\text { 10. Про засади державної }
$$
регуляторної політики у сфері господарської діяльності: Закон України від 26.11.2016 № 1160-15. - [Електронний ресурс]. - Режим доступу: http://zakon3.rada.gov.ua/laws/show/116015.

11. Про затвердження методик проведення аналізу впливу та відстеження 
результативності регуляторного акта : Постанова КМУ від 11.03.2004 р. № 308. [Електронний ресурс]. - Режим доступу: http://zakon3.rada.gov.ua/laws/show/3082004-\%D0\%BF

12. Про затвердження методик проведення аналізу впливу та відстеження результативності регуляторного акта Національного банку України : Постанова КМУ і Нацбанку України від 14.04.2004 p. № 471. - [Електронний ресурс]. - Режим доступу:

http://zakon3.rada.gov.ua/laws/show/4712004-\%D0\%BF

13. Радейко Р. I. Регуляторна політика в Україні: особливості формування і тенденції розвитку / P. I. Радейко // Вісник Національного університету «Львівська політехніка». Юридичні науки. - 2016. - № 837. - С. 100-104.

14. Noll R. G. Economic Perspectives on the Politics of Regulation / R. G. Noll // Handbook of Industrial Organization, edited by Richard Schmalensee and Robert Willig. Amsterdam: North Holland. - 1989. - Vol. 2. -pp. 1254-1287.

15. Thurow L. C. The Zero-Sum Society: Distribution And The Possibilities For Change / L. C. Thurow. - New York: Basic books, 2008. - 240 p.

\title{
УДК 352(082)
}

\section{ЕФЕКТИВНІСТЬ ДЕРЖАВНОГО УПРАВЛІННЯ ПОСТРАДЯНСЬКОЇ УКРАЇНИ}

\author{
Пащенко Ю.С., д.е.н., професор (НАУ)
}

У статті розглянуті проблеми розвитку основних галузей економіки, з якими зіткнулася Україна при переході на незалежний шлях розвитку. Підбито підсумки реформування економіки за 25-річний період, виявлені найбільш вагові причини економічних невдач, запропоновано заходи щодо їх усунення. Узагальнені численні розрізнені аналітичні дослідження на рівні макро і галузевої економіки. Вироботані конщептуальні пропозииї щцодо стабілізації та подальщого соціально-економічного зростання країни.

Ключові слова: динаміка макроекономічних показників, рівень життя населення, ВВП, індекси виробництва продукції промисловості і сільського господарства, транспорт, зовніиня торхівля, дерэнавний борг,банкова система.

\section{ЭФФЕКТИВНОСТЬ ГОСУДАРСТВЕННОГО УПРАВЛЕНИЯ ПОСТСОВЕТСКОЙ УКРАИНОЙ}

\section{Пащенко Ю.Е., д.э.Н., профессор (НАУ)}

В статье рассмотрены проблемы развития основных отраслей экономики, с которыли столкнулась Украина при переходе на независимьій путь развития. Подведень итоги реформирования экономики за 25-летний период, выявлены наиболее весомые причины экономических неудач, предложены мероприятия по их устранению. Обобщень многочисленные разрозненные аналитические исследования на уровне макро и отраслевой 